\title{
Urgences
}

\section{là sans que rien...}

\section{Michel Lévesque}

Numéro 15, octobre 1986

Épigraphiques

URI : https://id.erudit.org/iderudit/025302ar

DOI : https://doi.org/10.7202/025302ar

Aller au sommaire du numéro

Éditeur(s)

Urgences

ISSN

0226-9554 (imprimé)

1927-3924 (numérique)

Découvrir la revue

Citer ce document

Lévesque, M. (1986). là sans que rien... Urgences, (15), 35-35.

https://doi.org/10.7202/025302ar

Ce document est protégé par la loi sur le droit d'auteur. L'utilisation des services d'Érudit (y compris la reproduction) est assujettie à sa politique d'utilisation que vous pouvez consulter en ligne.

https://apropos.erudit.org/fr/usagers/politique-dutilisation/
Cet article est diffusé et préservé par Érudit.

Érudit est un consortium interuniversitaire sans but lucratif composé de l’Université de Montréal, l'Université Laval et l'Université du Québec à Montréal. Il a pour mission la promotion et la valorisation de la recherche. https://www.erudit.org/fr/ 


\section{Michel Lévesque}

Vous êtes le long de la mer,

Vous êtes le long de ces choses scellées entre elles par votre regard.

Marguerite Duras: L'homme atlantique

à Pierre

là sans que rien ne vienne esquisser la moindre ligne l'oeil suit cet homme trajectoire entre deux grains de sable sur la paume de ma main à peine légèrement mouillée

j'ai pris tant de temps à voir la longue montée du sang dans ce regard trop de temps je suis resté debout le visage découvert dans cette lumière un peu plus douce que le jour où j'ai crié à cette ombre profilêe

je n'irai plus à la mer pour y voir

je n'irai plus attendre comme avant jusqu'à la nuit le désordre des vagues quand il est là si près qu'il souffle rauque derrière mes mains mes yeux ne peuvent plus refuser l'empreinte le long de mon cou je n'ai laissé glisser que mon corps sur le sien son corps blanc des herbes de l'eau autour inventée la trace la courbe si offerte ma gorge sa main sa bouche je n'entends plus les vagues pourtant si proches j'entends son corps la nuit complice du jeu des regards bleus

la nuit si près de l'herbe du sable de l'eau 